\title{
CONSTRUCTING AN ENTREPRENEURSHIP PROJECT EVALUATION SYSTEM USING A HYBRID MODEL
}

\author{
Qi-Gan SHAO ${ }^{1,3}$, James J. H. LIOU ${ }^{*}$, Sung-Shun WENG ${ }^{3}$, Peiyao SU ${ }^{4}$ \\ ${ }^{1}$ School of Economics \& Management, Xiamen University of Technology, Xiamen, China \\ ${ }^{2}$ Department of Industrial Engineering and Management, \\ National Taipei University of Technology, Taipei, Taiwan \\ ${ }^{3}$ Department of Information and Finance Management, \\ National Taipei University of Technology, Taipei, Taiwan \\ ${ }^{4}$ Department of Education, Fujian Normal University, Fuzhou, China
}

Received 21 November 2019; accepted 15 April 2020

\begin{abstract}
Due to the economic trends around the world and the strong support and guidance of relevant governments, the number of entrepreneurial projects has soared in China. It is necessary to construct a standard assessment system for entrepreneurial projects that is comprehensive and effective. This study extracted six dimensions and 23 criteria for evaluating entrepreneurial projects. This study applies the best and worst methods to obtain the weights of the dimensions and criteria. Then, the Technique for Order Preference by Similarity to an Ideal Solution method was used to evaluate the entrepreneurial projects in an entrepreneurial competition. The results show that team quality, the business model and entrepreneurship ability are the three most important dimensions for evaluating entrepreneurial projects. The improvement of the innovating ability, the training of the team and the value proposition are the three keys to successful implementation of the entrepreneurial projects.
\end{abstract}

Keywords: entrepreneurial project, project evaluation, hybrid model, MCDM, BWM, TOPSIS.

JEL Classification: M13, D81, C61.

\section{Introduction}

Entrepreneurship is an important economic activity that supports the development of a country. Entrepreneurship creates social wealth and provides jobs, and recently, it has been received increasing attention (Fuentelsaz et al., 2019). Governments, universities and society are important players in promoting sustainable innovation and entrepreneurship (Åstebro et al., 2012). Many high-tech companies in Silicon Valley were incubated from well-known universities, such as Massachusetts Institute of Technology (MIT) and Stanford University

${ }^{\star}$ Corresponding author. E-mail: jamesjhliou@gmail.com

Copyright (C) 2020 The Author(s). Published by VGTU Press

This is an Open Access article distributed under the terms of the Creative Commons Attribution License (http://creativecommons. org/licenses/by/4.0/), which permits unrestricted use, distribution, and reproduction in any medium, provided the original author and source are credited. 
(Lee \& Eesley, 2018; David et al., 2007). Entrepreneurship has opened up new markets and provided new jobs for society (Aparicio et al., 2016). Entrepreneurship is one of the determinants of economic growth and development (Paul \& Shrivatava, 2016).

Since the Chinese government proposed that innovation and entrepreneurship are the main driving forces of China's economic development, Chinese governments, universities and enterprises have been committed to innovation, entrepreneurship education and project incubation (Zhu et al., 2017). Entrepreneurship has become one of the main ways to solve the employment problems in China (Chen et al., 2018). As the public awareness of innovation and entrepreneurship improve, small and micro enterprises continue to emerge in China. Entrepreneurship has become a vital source that contributes to the growth of employment. According to a report by the National Bureau of Statistics of China, there were on average 15,000 new registered businesses daily in 2016, and that number increased to over 16,000 in 2017 (Zhang, 2018).

This study aims to develop a model for evaluating entrepreneurial projects. First, this paper summarize the methods and evaluation criteria of project evaluation by previous scholars, and point out the differences of this paper, and introduce the BWM method applied in this paper and the application of this method. Then, this paper extracts the evaluation dimensions and criteria through a review of the literature. Then, the weights of the dimensions and criteria are determined using the BWM. Next, the Technique for Order Preference by Similarity to Ideal Solution (TOPSIS) is applied to investigate the gap between each project's performance and target level. Furthermore, identifying the shortcomings of entrepreneurial projects and improving their quality are also important goals of this article. By applying the evaluation system to specific projects, this study can identify the directions for improvement for projects across all dimensions and criteria and increase their success rates.

The rest of this paper is organized as follows. Section 1 gives a brief review of the relevant literature. Section 2.1 describes the BWM method that is used to find the weights of the criteria, and Section 2.2 introduces the TOPSIS algorithm that is used to evaluate and rank the performance of the projects. Data collected from expert interviews are analyzed in Section 3. The results are discussed in Section 4, and the summaries and limitations are presented in last Section.

\section{Literature review}

Experts in project management began to pay attention to the factors affecting the success of project operation at an early age (Cooke-Davis, 2002). Ika (2009) argued that time, cost and quality would have an impact on the successful implementation of the project. Salunke et al. (2013) proposed service innovation is very important to improve the competitiveness of entrepreneurial projects. Soares et al. (2013) considered that soft skills like project management, teamwork, communication ability are needed to be improved to enhance the quality of students' entrepreneurship projects. Although these literature focus on the success factors of project implementation, they ignore the important aspects of technology, market, finance, etc. The evaluation of project performance is carried out in a multi-dimensional and complex 
context. From this point of view, project evaluation needs to consider team, market, leader and other aspects (Durmuşoğlu, 2018). On the other hand, different from other literature, this paper takes entrepreneurship project as the research object, which has important practical significant. In recent years, the Chinese government has vigorously promoted "mass entrepreneurship, mass innovation", and young people with college students as the main body have made use of the resources provided by the government, schools and society to actively start innovative enterprises. It's critical to evaluate and support these startups. Therefore, it is an important innovation to evaluate the operation of entrepreneurial projects from multiple dimensions in this paper.

Entrepreneurial projects are efforts of entrepreneurs to identify, evaluate and develop potential opportunities (Patzelt et al., 2020). Pickernell et al. (2011) has studied the performance of entrepreneurial projects in terms of their funding, public support, and other external resources. Pirzada et al. (2015) uses the focus method and correlation analysis to study the performance of Indonesian entrepreneurial projects. Mandel and Noyes (2016) lists the top 25 entrepreneurial education courses in entrepreneurship schools in the United States, that were designed to provide experiential entrepreneurship, and uses surveys to determined the most valuable factors in top entrepreneurial projects.

In general, an entrepreneurial project begins with an initial business plan or an innovative business model. Entrepreneurs seek to increase the awareness of their projects through business plans and roadshows, which in turn, may be supported by governments and investors. The support decision for a project depends on the quality of the project. The quality of the project needs to be measured from multiple perspectives. The factors that influence the quality of entrepreneurial projects are multidimensional and complex. Due to the different capabilities of entrepreneurial teams and different modes of entrepreneurial projects, the quality of entrepreneurial projects greatly varies. As a result, choosing the right project to support is not an easy task. The evaluation of entrepreneurial projects is a multiple-criteria decision-making (MCDM) problem. MCDM methods solve complex decision problems through structured and logical modeling (Kalbar et al., 2012). According to the literature we have consulted, few experts use MCDM method to evaluate entrepreneurial projects. With the continuous development of MCDM models, the Best and Worst Method (BWM) has been one of the most powerful models for evaluating complex multiple alternatives involving subjective judgments (Salimi \& Rezaei, 2016; You et al., 2016; Mou et al., 2016; Guo \& Zhao, 2017). This method has been proven to be simpler and more reliable than the traditional Analytic Hierarchy Process (AHP) method (Rezaei, 2015; Rezaei et al., 2017). Experts have applied BWM method to research in many fields. Gupta and Barua (2017) used BWM and TOPSIS method to identify some ways to solute the barriers that affect the green innovation in SMEs. Rahimi et al. (2020) applied fuzzy group BWM method for selection sustainable landfill site. Gupta (2018) used BWM and fuzzy TOPSIS to assess organizations performance on the basis of green human resource management practices (GHRM). Kumar et al. (2020) used BWM and VIKOR method to evaluate green performance of the airports. 


\section{Methodology}

First, this paper combs out the dimensions and criteria that affect the performance of entrepreneurial projects. To evaluate entrepreneurial projects, a hybrid multiple-criteria decisionmaking framework that combines the BWM with the TOPSIS is proposed in this paper. This paper introduces the principle and steps of the BWM method that is used to obtain the optimal weights in 2.2. The TOPSIS method that is used to evaluate the performance of college entrepreneurial projects is presented in section 2.3 .

\subsection{Dimensions for entrepreneurial projects evaluation}

This paper proposed a relatively complete model for evaluating entrepreneurial projects in a complex multi-dimension environment. To select good startup projects for further incubation, this paper chooses team quality, entrepreneurship ability, the business model, the market environment, the financial environment and the entrepreneur environment as six dimensions for evaluating the quality of a project.

\section{(1) Team quality (D1)}

The key to the success of an entrepreneurial project is the quality of the entrepreneurial team. There are many indicators for measuring team quality, and scholars have provided different opinions about them. İrengün and Arıkboğa (2015) proposes that people should be inclined to encourage entrepreneurs with professionalism, entrepreneurial enthusiasm and adventurous spirits, and emphasizes the importance of leadership and teamwork. Gartner (1990) believes that executive power and team responsibility are important factors in the students' entrepreneurship. Kirkwood et al. (2014) and Jensen (2014) assessed the importance of entrepreneurship education for team entrepreneurship. This study proposes that the team leader ability, professionalism, entrepreneurial enthusiasm, team spirit, team discipline and execution, and acceptance of entrepreneurship education are the six indicators that reflect the quality of a startup team.

\section{(2) Entrepreneurship ability (D2)}

Entrepreneurship ability is the core of an entrepreneurial project, and it determines whether the project continues to successfully operate. In this paper, the difference between team quality and entrepreneurship ability is that the former is based on the personal qualities of team members, while the latter is mainly the required skills and abilities. Yang and Gabrielsson (2017) emphasizes the importance of high-tech enterprises in applying professional skills to reduce market uncertainty when marketing to industrial markets. Avlonitis and Salavou (2007) argues that innovation and the risk response ability are extremely important for entrepreneurial projects. Alvarez and Busenitz (2001) argued that the stronger the ability of entrepreneurs to integrate resources, the higher the economic value they can create. Based on the above-mentioned literature, this paper defines the indicators in this dimension as professional skills, innovation ability, risk response, and resource integration ability. 


\section{(3) Business model (D3)}

The business model is a production system that transforms an entrepreneur's originality into a business idea and then evolves it into a creative combination. A business model should deliver value to customers (Fjeldstad \& Snow, 2018). Businesses provide value to consumers through products or services (Hienerth et al., 2011). Value creation is the core of any business. Start-ups are sustainable because they capture new market opportunities based on new products (Beltramello et al., 2013). As a result, this study uses value creation as one of the indicators for measuring business models.

The value proposition is the economic return obtained after providing the target customer with a product or service (Bocken et al., 2014). Entrepreneurship projects need to explain whether their new products and services can solve market needs through the value proposition. Chesbrough and Rosenbloom (2002) suggest that business models should include indicators, such as the value proposition, profit model, value system, and competitive strategy. While profit model is the basis for survival of start-ups, and value systems and competitive strategies have not yet formed an advantage for the initial entrepreneurs. Therefore, this paper selects value proposition and profit model as indicators. As global sustainability pressures increase and companies fiercely compete, cooperation between companies and other key stakeholders becomes more important (Geissdoerfer et al., 2018). It is especially important to maintain close contact with stakeholders such as suppliers, customers, and the media. Therefore, this study believe that resource integration capabilities are also an important part of a well-established business model for start-ups.

\section{(4) Marketing environment (D4)}

A good market environment guarantees the stable survival and development of entrepreneurial projects. Artificial intelligence, big data, blockchains and other technical applications are the future development directions of the industry (Allam \& Dhunny, 2019; Duan et al., 2019; Yang et al., 2019). These technologies also provide ideas and directions for entrepreneurs to start a business. Finkle and Deeds (2001) propose that entrepreneurs should choose projects that meet market needs, and these types of projects are easier to quickly incubate and are favored by investors. The market share of products is also a barometer for assessing the operation of a project (Razeghian \& Weber, 2019). If an industry has many competitors and competition is fierce, the industry is not suitable for start-ups (W. Kim \& M. Kim, 2015). Therefore, this study use the industry outlook, market needs, market share and competitive structure as the four indicators to measure the market environment.

\section{(5) Financial environment (D5)}

As is known, a project needs startup funding and, and financing in the middle and late stages of the project to survive. Enterprises need financial support at the beginning of their businesses (Colombo et al., 2019). Many entrepreneurs start their own businesses on campus, and their growth requires the support of the government, universities and social enterprises (Wen et al., 2018; Dahaj \& Cozzarin, 2019). Frid et al. (2016) believes that whether companies can obtain external financing is determined by the company itself and there is a gap between low 
wealth and high wealth enterprises in obtaining external financing. Initial funds and future entrepreneurial financing are the two indicators that reflect the financial environment.

\section{(6) Entrepreneur environment (D6)}

In the early stage of a venture, the incubation and development of the project cannot be separated from the support of external resources. Tsai and Kuo (2011) and Lucia et al. (2016) describe the role of national policies in promoting entrepreneurial projects. Cui et al. (2019) believes that in addition to national policy beings is beneficial to the development of entrepreneurial projects, the support of universities and the realistic demands of social development also play important roles in entrepreneurial projects. Sustainable development policies have accelerated the public's focus on sustainable development projects. Khalili-Damghani and Sadi-Nezhad (2013) propose that a sustainable strategy has a positive effect on social and economic values of new ventures. Neumeyer and Santos (2018) argues that sustainable business models are not only business models, network theories and ecosystems, but also supportive entrepreneurial ecosystems that are different from traditional business models. Therefore, this study considers policy support, school entrepreneurship support and sustainable development as the three indicators to measure the entrepreneur environment. Table 1 summarizes the above dimensions, criteria and their references.

\subsection{BWM method}

Since Rezaei (2015) proposed the BWM method, it has been favored by researchers because it has significantly better data consistency than the AHP method and requires less fewer comparative data to produce more reliable results. The BWM method determines the best and worst indicators via decision makers, then compares them with other standards, finally, obtains the best choice (Gupta \& Barua, 2017).

This study compares the dimensions (criteria) that affect the performance of entrepreneurial projects, and calculate the weights of the dimensions and criteria in the system through quantitative analysis. The specific steps are as follows.

Step 1: Identify the range of the decision criteria. The standard sets $\left\{z_{1}, z_{2}, z_{3}, \ldots, z_{n}\right\}$ that are used to evaluate the entrepreneurial projects' performance are obtained from a literature review.

Step 2: Determine the best (such as the most desirable, most important) dimension (criterion) and the worst (such as the most undesirable, least important) dimension (criterion).

Step 3: The degree of preference between the best dimension (criterion) and other dimension (criterion) is determined by a number between 1 and 9. The result is the best - other (BO) vectors. The preference for the best criterion with respect to the other criteria should be expressed as $Z_{B}=\left(z_{B 1}, z_{B 2}, z_{B 3}, \ldots, z_{B n}\right)$, where $Z_{B o}$ represents the preferences for the best dimension (criterion) with respect to the other dimension (criterion) $o$, and obviously, $z_{B B}=1$.

Step 4: The degree of preference between other dimensions (criteria) to the worst dimension (criterion) is determined using numbers between 1 and 9 , which results in the otherworst (OW) vectors: $Z_{W}=\left(z_{1 W}, z_{2 W}, z_{3 W}, \ldots, z_{n W}\right)^{T}$, where $Z_{o w}$ represents the preferences for the other dimensions (criteria) with respect to the worst dimension (criterion), and obviously, $z_{W W}=1$. 
Table 1. The references of the dimension's indicators

\begin{tabular}{|c|c|c|}
\hline Dimension & Criteria & Reference literature \\
\hline \multirow{6}{*}{$\begin{array}{l}\text { Team quality } \\
\left(D_{1}\right)\end{array}$} & Team leader ability $\left(C_{11}\right)$ & İrengün and Arıkboğa (2015) \\
\hline & Professionalism $\left(C_{12}\right)$ & İrengün and Arıkboğa (2015) \\
\hline & $\begin{array}{l}\text { Entrepreneurial enthusiasm } \\
\left(C_{13}\right)\end{array}$ & İrengün and Arıkboğa (2015) \\
\hline & Team spirit $\left(C_{14}\right)$ & Gartner (1990) \\
\hline & $\begin{array}{l}\text { Team discipline and } \\
\text { execution }\left(C_{15}\right)\end{array}$ & Gartner (1990) \\
\hline & $\begin{array}{l}\text { Acceptance of } \\
\text { entrepreneurship } \\
\text { education }\left(C_{16}\right)\end{array}$ & $\begin{array}{l}\text { Kirkwood et al. (2014) } \\
\text { Jensen (2014) }\end{array}$ \\
\hline \multirow{4}{*}{$\begin{array}{l}\text { Entrepreneurship } \\
\text { ability } \\
\left(D_{2}\right)\end{array}$} & Professional skills $\left(C_{21}\right)$ & Yang and Gabrielsson (2017) \\
\hline & Innovative ability $\left(C_{2) 2}\right.$ & Avlonitis and Salavou (2007) \\
\hline & Risk response $\left(C_{23}\right)$ & Avlonitis and Salavou (2007) \\
\hline & $\begin{array}{l}\text { Resource integration ability } \\
\left(C_{24}\right)\end{array}$ & Alvarez and Busenitz (2001) \\
\hline \multirow{4}{*}{$\begin{array}{l}\text { Business model } \\
\left(D_{3}\right)\end{array}$} & Value creation $\left(C_{31}\right)$ & $\begin{array}{l}\text { Fjeldstad and Snow (2018), Hienerth et al. } \\
\text { (2011), Beltramello et al. (2013) }\end{array}$ \\
\hline & Value proposition $\left(C_{32}\right)$ & $\begin{array}{l}\text { Fjeldstad and Snow (2018), Bocken et al. } \\
(2014), \text { Chesbrough and Rosenbloom } \\
(2002)\end{array}$ \\
\hline & Profit model $\left(C_{33}\right)$ & Chesbrough and Rosenbloom (2002) \\
\hline & Value share $\left(C_{34}\right)$ & $\begin{array}{l}\text { Fjeldstad and Snow (2018), Geissdoerfer } \\
\text { et al. (2018) }\end{array}$ \\
\hline \multirow{4}{*}{$\begin{array}{l}\text { Market environment } \\
\left(D_{4}\right)\end{array}$} & Industry outlook $\left(C_{41}\right)$ & $\begin{array}{l}\text { Allam and Dhunny (2019), Duan et al. } \\
\text { (2019), Yang et al. (2019) }\end{array}$ \\
\hline & Market needs $\left(C_{42}\right)$ & Finkle and Deeds (2001) \\
\hline & Market share $\left(C_{43}\right)$ & Razeghian and Weber (2019) \\
\hline & Competitive structure $\left(C_{44}\right)$ & W. Kim and M. Kim (2015) \\
\hline \multirow{2}{*}{$\begin{array}{l}\text { Financial } \\
\text { environment } \\
\left(D_{5}\right)\end{array}$} & Initial funds $\left(C_{51}\right)$ & Colombo et al. (2019) \\
\hline & $\begin{array}{l}\text { Entrepreneurial future } \\
\text { financing }\left(C_{52}\right)\end{array}$ & $\begin{array}{l}\text { Wen et al. (2018), Dahaj and Cozzarin } \\
\text { (2019), Frid et al. (2016) }\end{array}$ \\
\hline \multirow{3}{*}{$\begin{array}{l}\text { Entrepreneurial } \\
\text { environment } \\
\left(D_{6}\right)\end{array}$} & Policy support $\left(C_{61}\right)$ & $\begin{array}{l}\text { Tsai and Kuo (2011), Lucia et al. (2016), Cui } \\
\text { et al. (2019) }\end{array}$ \\
\hline & $\begin{array}{l}\text { School entrepreneurship } \\
\text { support }\left(C_{62}\right)\end{array}$ & Cui et al. (2019) \\
\hline & $\begin{array}{l}\text { Sustainable development } \\
\left(C_{63}\right)\end{array}$ & $\begin{array}{l}\text { Khalili and Sadi-Nezhad (2013) } \\
\text { Neumeyer and Santos (2018) }\end{array}$ \\
\hline
\end{tabular}


Step 5: Find the optimal weight combination set $\left(w_{1}^{*}, w_{2}^{*}, w_{3}^{*}, \ldots, w_{n}^{*}\right)$. It can be determined that the maximum and minimum absolute values in this set are $\left|\frac{w_{B}}{w_{m}}-z_{B m}\right|$ and $\left|\frac{w_{m}}{w_{W}}-z_{m W}\right|$, respectively. The maximum and minimum absolute values can be determined using the following formula.

$$
\begin{aligned}
& \text { min max model: } \quad \quad \quad \min \max _{m}\left\{\left|\frac{w_{B}}{w_{m}}-z_{B j}\right|,\left|\frac{w_{m}}{w_{W}}-z_{m W}\right|\right\} \\
& \text { s.t. } \\
& \sum_{m} w_{m}=1 \text {, }
\end{aligned}
$$

when $w_{m} \geq 0$, it is tenable for all $m$.

Model (1) is equal to the following model:

$$
\begin{gathered}
\min z \\
\text { s.t. } \\
\left|\frac{w_{B}}{w_{m}}-z_{B m}\right| \leq z \text { which is tenable for all } m ; \\
\left|\frac{w_{m}}{w_{W}}-z_{m W}\right| \geq z \text { which tenable for all } m ; \\
\sum_{m} w_{m}=1,
\end{gathered}
$$

when $w_{m} \geq 0$, it is tenable for all $m$.

Rezaei (2015) noted that the consistency of the results of testing the BWM model is as follows:

Definition 1: When $z_{B m} \times z_{m W}=z_{B W}$, the comparison is fully consistent. The preference for the best dimension (criterion) to dimension (criterion) $m$, the preference for dimension (criterion) $m$ to the worst dimension (criterion) and the preference for the best dimension (criteria) to the worst are $z_{B m}, z_{m W}, z_{B W}$, respectively (Liang et al., 2020). Table 2 shows the maximum values of $z$ (consistency indicators) for the different values of $z_{B W}$.

Table 2. Consistency indicators (CI)

\begin{tabular}{|c|c|c|c|c|c|c|c|c|c|}
\hline$z_{B W}$ & 1 & 2 & 3 & 4 & 5 & 6 & 7 & 8 & 9 \\
\hline Consistency Indicators $(\mathrm{CI})$ & 0.00 & 0.44 & 1.00 & 1.63 & 2.30 & 3.00 & 3.73 & 4.47 & 5.23 \\
\hline
\end{tabular}

Based on the consistency indicators (Table 2), the consistency rate (CR) is calculated as follows:

$$
C R=\frac{z^{*}}{C I}
$$

The consistency rate is measured as a value between 0 and 1 . The closer the value to 0 , the higher the consistency. 


\subsection{TOPSIS}

The TOPSIS (Technique for Order Preference by Similarity to Ideal Solution) method was first proposed by Hwang and Yoon in 1981 (Hwang \& Yoon, 1981). The TOPSIS method uses the distance relationship between data sequences as a metric and can be used to estimate the location relationship between schemes. Yoon and Kim (2017) proposed an improved TOPSIS method. The specific steps are as follows.

Step 1: Obtain the original data matrix of projects based on expert interviews. The specific form is as follows:

$$
D_{p}=\left(o_{p 1}, \ldots, o_{p q}, \ldots, o_{p n}\right), p=1, . ., m
$$

where $D_{p}$ means the original data matrix and $o_{p q}$ represents the performance value of the $q$-th indicator of the $p$-th project. $m$ means the number of projects, and $n$ means the number of indicators.

Step 2: Normalize the original data matrix $D_{p}$. Then, this paper transform the all the criteria into the same non-dimensional features so that the performance values of the criteria can be compared with each other. The specific formula is as follows:

$$
u_{p q}=\frac{o_{p q}}{\sqrt{\sum_{p=1}^{m} o_{p q}^{2}}}, p=1, \ldots m ; q=1, \ldots, n
$$

where $u_{p q}$ represents the evaluation values of project $p$ under $q$ evaluation criteria.

Step 3: Establish a standardized weight matrix $w=\left(w_{1}, w_{2}, \ldots \ldots, w_{q}, \ldots \ldots, w_{n}\right)$. The weights of each criterion are derived from the BWM method introduced in Section 3.1. The evaluation matrix is obtained multiplying the weight matrix multiplied by the standardized evaluation matrix. The specific formula is as follows:

$$
\begin{gathered}
k_{p q}=w_{q} u_{p q}, p=1, \ldots, m ; q=1, \ldots, n ; \\
k=\left[\begin{array}{cccc}
k_{11} & k_{12} & \ldots & k_{1 n} \\
k_{21} & k_{22} & \ldots & k_{2 n} \\
\vdots & \vdots & \ddots & \vdots \\
k_{m 1} & k_{m 2} & \ldots & k_{m n}
\end{array}\right]=\left[\begin{array}{cccc}
w_{1} u_{11} & w_{2} u_{12} & \ldots & w_{n} u_{1 n} \\
w_{1} u_{21} & w_{2} u_{22} & \ldots & w_{n} u_{2 n} \\
\vdots & \vdots & \ddots & \vdots \\
w_{1} u_{m 1} & w_{2} u_{m 2} & \ldots & w_{n} u_{m n}
\end{array}\right],
\end{gathered}
$$

where $w_{q}$ means the weight of criterion $q$, and $k_{p q}$ is the weighted performance value of the $q$-th indicator of the $p$-th project.

Step 4: Determine the ideal solution $\left(T^{*}\right)$ and the negative ideal solution $\left(T^{-}\right)$. The ideal solution is that with the greatest value of interest to the alternative, and the negative ideal solution is the one that the least value of interest to the alternative.

$$
\begin{aligned}
& T^{*}=\left\{\left\lfloor\max _{p} k_{p q} \mid p \in P\right\rfloor,\left|\max _{p} k_{p q}\right| p \in P^{\prime}|| p=1,2, \ldots, m\right\}=\left\{k_{1}^{*}, k_{2}^{*}, \ldots, k_{p}^{*}, k_{n}^{*}\right\} ; \\
& T^{-}=\left\{\left\lfloor\min _{p} k_{p q} \mid p \in P\right\rfloor,\left|\max _{p} k_{p q}\right| p \in P^{\prime}|| p=1,2, \ldots, m\right\}=\left\{k_{1}^{-}, k_{2}^{-} \ldots, k_{p}^{-}, k_{n}^{-}\right\} .
\end{aligned}
$$


Step 5: Separate the calculations of measure $G_{p}^{*}$ and measure $G_{p}^{-}$, and separate the distance between the optimal solution and the worst solution. The specific formula is as follows:

$$
\begin{aligned}
& G_{p}^{*}=\sqrt{\sum_{q=1}^{n}\left(k_{p q}-k_{p}^{*}\right)^{2}}, p=1,2, \ldots, m ; \\
& G_{p}^{-}=\sqrt{\sum_{q=1}^{n}\left(k_{p q}-k_{p}^{-}\right)^{2}}, p=1,2, \ldots, m .
\end{aligned}
$$

Step 6: Calculate the relative closeness of the ideal solution $H_{p}^{*}$. The closer the $H_{p}^{*}$ value is to 1 , the closer the alternative solution is to the ideal solution.

$$
H_{p}^{*}=\frac{G_{p}^{-}}{G_{p}^{*}+G_{p}^{-}}
$$

Step 7: Calculate the size of $H_{p}^{*}$ and sort it to obtain the best solution.

\section{Data analysis}

This study assessed a real case to demonstrate the usefulness of the proposed model. The China "Internet +" College Students Innovation and Entrepreneurship Competition is an important event hosted by the Chinese Ministry of Education. The competition aims to improve the innovation and entrepreneurship of young Chinese college students and to finance good entrepreneurial projects. The competition attracted a total of 1.57 million teams composed of 4.57 million college students worldwide in 2019. The competition is divided into four levels, which are school-level events, college-level events, provincial events and national events. This study applied the proposed model to the school-level competition of the School of Economics and Management of Xiamen University of Technology. Ten experts were invited to participate in this event. They consisted of 5 entrepreneurs with more than 10 years of entrepreneurial experience and 5 professors who study entrepreneurship management. The rules of college level competition are as follows: the college informs the student team to submit the business plan by may 2019 through the network platform, and the organizer will preliminarily select five excellent projects according to the business plan, and then the selected projects will have the opportunity to participate in the college level final.The top three out of five entrepreneurial projects are selected to compete at higher levels. The purpose of inviting 10 experts was to evaluate the quality of these five projects, to rank their performances, and to select the best projects.

This study interviewed 10 experts in different scenarios and asked them to fill out questionnaires. A total of two questionnaires were designed for this study. Questionnaire 1 was used to evaluate the importance of the six dimensions and 23 criteria, and questionnaire 2 was used to evaluate the performance of the five entrepreneurial projects. The specific implementation process is as follows. 


\subsection{Weight calculation}

This study applied the BWM method as described in Section 3 to evaluate the entrepreneurial projects through six dimensions and 23 indicators. First, ten experts were asked to find the most important dimension from the six dimensions and the most important criterion in each dimension. The least important dimension and criterion were also determined based on the experts' opinions. Table 3 shows the best and worst dimensions selected by experts. Five experts argued that team quality $\left(D_{1}\right)$ was the most important dimension, three experts thought that the business model $\left(D_{3}\right)$ was the most important dimension, and two experts considered entrepreneurship ability $\left(D_{2}\right)$ to be the most important. Conversely, four experts selected the market environment $\left(D_{4}\right)$ and another four experts selected the financial environment $\left(D_{5}\right)$ as the worst dimension, while only one expert chose the business model $\left(D_{3}\right)$ as the worst. Similarity, the experts found the best and worst criteria for each dimension in the same way.

Table 3. The most important and the least important dimension of expert selection

\begin{tabular}{|c|c|c|}
\hline Dimension & $\begin{array}{c}\text { Expert's number for most important } \\
\text { dimensions }\end{array}$ & $\begin{array}{c}\text { Expert's number for the least important } \\
\text { dimensions }\end{array}$ \\
\hline$D_{1}$ & $1,3,4,5,7$ & \\
\hline$D_{2}$ & 2,8 & 1 \\
\hline$D_{3}$ & $6,9,10$ & \\
\hline$D_{4}$ & & $2,5,9,10$ \\
\hline$D_{5}$ & & $3,4,6,7,8$ \\
\hline$D_{6}$ & & \\
\hline
\end{tabular}

Second, 10 experts were invited to determine the preference for the best dimension (criterion within each dimension) over other dimensions (other criteria within each dimension) and the preference for all others over the worst dimension or criterion by using the evaluation scale shown in Table 4. As seen in Table 5, the first expert thought that team quality $\left(D_{1}\right)$ was extremely more important than business model $\left(D_{3}\right)$, with the value 9 . Table 6 indicates the preference value of all other dimensions over the worst dimension. The preference values of the best criterion over all other criteria within each dimension and of all others over the worst were obtained using the same procedures.

Table 4. Evaluation scales

\begin{tabular}{|c|l|l|}
\hline Evaluation scale & \multicolumn{1}{|c|}{ Definition } & \multicolumn{1}{c|}{ Explanation } \\
\hline 1 & equally important & The two factors are of equal importance when compared \\
\hline 3 & weakly important & $\begin{array}{l}\text { Comparing the two factors, one is slightly more important } \\
\text { than another }\end{array}$ \\
\hline 5 & Obviously important & $\begin{array}{l}\text { Comparing the two factors, one is obviously more } \\
\text { important than another }\end{array}$ \\
\hline 7 & Very important & $\begin{array}{l}\text { Comparing the two factors, one is more important than } \\
\text { another }\end{array}$ \\
\hline 9 & Extremely important & $\begin{array}{l}\text { Comparing the two factors, one is extremely important } \\
\text { than another }\end{array}$ \\
\hline $2,4,6,8$ & - & The intermediate value of the adjacent judgment above \\
\hline
\end{tabular}


Table 5. BO dimension vectors for the 10 experts

\begin{tabular}{|c|c|c|c|c|c|c|c|}
\hline Expert No. & Best & $D_{1}$ & $D_{2}$ & $D_{3}$ & $D_{4}$ & $D_{5}$ & $D_{6}$ \\
\hline 1 & $D_{1}$ & 1 & 8 & 9 & 7 & 7 & 7 \\
\hline 2 & $D_{2}$ & 3 & 1 & 2 & 7 & 9 & 7 \\
\hline 3 & $D_{1}$ & 1 & 1 & 3 & 5 & 4 & 9 \\
\hline 4 & $D_{1}$ & 1 & 5 & 3 & 3 & 1 & 7 \\
\hline 5 & $D_{1}$ & 1 & 3 & 5 & 3 & 9 & 7 \\
\hline 6 & $D_{3}$ & 3 & 3 & 1 & 5 & 3 & 8 \\
\hline 7 & $D_{1}$ & 1 & 5 & 3 & 3 & 3 & 9 \\
\hline 8 & $D_{2}$ & 3 & 1 & 5 & 3 & 3 & 8 \\
\hline 9 & $D_{3}$ & 3 & 3 & 1 & 5 & 9 & 6 \\
\hline 10 & $D_{3}$ & 3 & 3 & 1 & 5 & 9 & 3 \\
\hline
\end{tabular}

Table 6. OW dimension vectors for the 10 experts

\begin{tabular}{|c|c|c|c|c|c|c|c|c|c|c|}
\hline Expert No. & 1 & 2 & 3 & 4 & 5 & 6 & 7 & 8 & 9 & 10 \\
\hline worst & $D_{3}$ & $D_{5}$ & $D_{6}$ & $D_{6}$ & $D_{5}$ & $D_{6}$ & $D_{6}$ & $D_{6}$ & $D_{5}$ & $D_{5}$ \\
\hline$D_{1}$ & 9 & 7 & 9 & 7 & 9 & 5 & 9 & 5 & 6 & 5 \\
\hline$D_{2}$ & 4 & 9 & 5 & 3 & 5 & 3 & 5 & 8 & 5 & 7 \\
\hline$D_{3}$ & 1 & 8 & 7 & 5 & 4 & 8 & 3 & 5 & 9 & 9 \\
\hline$D_{4}$ & 3 & 4 & 5 & 5 & 2 & 3 & 2 & 3 & 5 & 5 \\
\hline$D_{5}$ & 2 & 1 & 3 & 3 & 1 & 1 & 3 & 2 & 1 & 1 \\
\hline$D_{6}$ & 2 & 4 & 1 & 1 & 2 & 1 & 1 & 1 & 3 & 7 \\
\hline
\end{tabular}

Then, by applying the data presented in Tables 5 and 6 to Eq. (2) in Section 3.1, 10 weights for the six dimensions and 23 criteria were obtained. The consistency of the 10 the expert questionnaires was determined based on Table 2 and Eq. (3). Due to space limitations, this paper only provides the results of the dimensions involved in the questionnaire. The method for calculating the weights of each criterion in each dimension is the same as the above steps. The final weights of the six dimensions and 23 criteria are shown in Table 7.

Table 7. Summary of dimensions and weights of indicators

\begin{tabular}{|l|l|l|c|c|}
\hline \multirow{2}{*}{ Dimensions } & Weights & \multicolumn{1}{|c|}{ Criteria } & $\begin{array}{c}\text { Local } \\
\text { weights }\end{array}$ & $\begin{array}{c}\text { Global } \\
\text { weights }\end{array}$ \\
\hline \multirow{5}{*}{$\begin{array}{c}\text { Team quality } \\
\left(D_{1}\right)\end{array}$} & \multirow{3}{*}{$0.308(1)$} & Team leader ability $\left(C_{11}\right)$ & 0.302 & $0.093(2)$ \\
\cline { 3 - 5 } & Professionalism $\left(C_{12}\right)$ & 0.140 & $0.043(12)$ \\
\cline { 3 - 5 } & \begin{tabular}{l} 
Entrepreneurial enthusiasm $\left(C_{13}\right)$ \\
\cline { 3 - 5 }
\end{tabular} & Team spirit $\left(C_{14}\right)$ & 0.139 & $0.043(13)$ \\
\cline { 3 - 6 } & Team discipline and execution $\left(C_{15}\right)$ & 0.218 & $0.067(4)$ \\
\cline { 3 - 6 } & $\begin{array}{l}\text { Acceptance of entrepreneurship education } \\
\left(C_{16}\right)\end{array}$ & 0.152 & $0.047(8)$ \\
\hline
\end{tabular}


End of Table 7

\begin{tabular}{|c|c|c|c|c|}
\hline Dimensions & Weights & Criteria & $\begin{array}{l}\text { Local } \\
\text { weights }\end{array}$ & $\begin{array}{l}\text { Global } \\
\text { weights }\end{array}$ \\
\hline \multirow{4}{*}{$\begin{array}{l}\text { Entrepre- } \\
\text { neurship } \\
\text { ability } \\
\left(D_{2}\right)\end{array}$} & \multirow{4}{*}{$0.196(3)$} & Professional skills $\left(C_{21}\right)$ & 0.136 & $0.027(17)$ \\
\hline & & Innovative ability $\left(C_{22}\right)$ & 0.484 & $0.095(1)$ \\
\hline & & Risk response $\left(C_{23}\right)$ & 0.142 & $0.028(16)$ \\
\hline & & $\begin{array}{l}\text { Resource integration ability } \\
\left(C_{24}\right)\end{array}$ & 0.238 & $0.046(9)$ \\
\hline \multirow{4}{*}{$\begin{array}{l}\text { Business } \\
\text { model } \\
\left(D_{3}\right)\end{array}$} & \multirow{4}{*}{$0.212(2)$} & Value creation $\left(C_{31}\right)$ & 0.282 & $0.060(5)$ \\
\hline & & Value proposition $\left(C_{32}\right)$ & 0.417 & $0.088(3)$ \\
\hline & & Profit model $\left(C_{33}\right)$ & 0.216 & $0.046(10)$ \\
\hline & & Value share $\left(C_{34}\right)$ & 0.085 & $0.018(21)$ \\
\hline \multirow{4}{*}{$\begin{array}{l}\text { Market } \\
\text { environment } \\
\left(D_{4}\right)\end{array}$} & \multirow{4}{*}{$0.118(4)$} & Industry outlook $\left(C_{41}\right)$ & 0.282 & $0.033(14)$ \\
\hline & & Market needs $\left(C_{42}\right)$ & 0.449 & $0.053(6)$ \\
\hline & & Market share $\left(C_{43}\right)$ & 0.112 & $0.013(23)$ \\
\hline & & Competitive structure $\left(C_{44}\right)$ & 0.157 & $0.019(20)$ \\
\hline \multirow{2}{*}{$\begin{array}{l}\text { Financial } \\
\text { environment } \\
\left(D_{5}\right)\end{array}$} & \multirow{2}{*}{$0.093(5)$} & Initial funds $\left(C_{51}\right)$ & 0.485 & $0.045(11)$ \\
\hline & & Entrepreneurial future financing $\left(C_{52}\right)$ & 0.515 & $0.048(7)$ \\
\hline \multirow{3}{*}{$\begin{array}{l}\text { Entrepre- } \\
\text { neurial } \\
\text { environment } \\
\left(D_{6}\right)\end{array}$} & \multirow{3}{*}{$0.074(6)$} & Policy support $\left(C_{61}\right)$ & 0.283 & $0.021(19)$ \\
\hline & & School entrepreneurship support $\left(C_{62}\right)$ & 0.308 & $0.023(18)$ \\
\hline & & Sustainable development $\left(C_{63}\right)$ & 0.409 & $0.030(15)$ \\
\hline
\end{tabular}

Note: The parentheses () indicate the ranking.

\subsection{Projects performance evaluation}

After obtaining 23 criteria weights, 10 experts were invited to serve as judges in the entrepreneurship competition. These experts listened to the five entrepreneurship teams report on their projects and then asked questions. Each team has 10 minutes for project report, and each team also had 10 minutes to answer the experts' questions. The first project developed an Internet platform that sells used cars, which was named fan car (FC). The second team developed as smart pension (SP), and planned to incorporate artificial intelligence into medical equipment to care for elderly people. The third project was focused on selling tea through an e-commerce platform which was called tea farmer (TF). The fourth project was a smart shoe washing project named the smart washing machine (SWM). The last project was about waste sorting (WS). The team proposed a solution for urban waste sorting. At the end of each project's defense, the 10 judges scored the 23 criteria for the five projects based on questionnaire 2, each of which was scored using a value from 1 to 10. After obtaining the survey results, this study calculated the performances of the five projects based on the TOPSIS method introduced in Section 3.2. The steps for solving the problem are as follows. 
Step 1: Based on the 10 experts' surveys, this study normalized the performance values according to Eq. (5), and the results are shown in Table 8.

Table 8. Normalized matrix of performance data

\begin{tabular}{|c|c|c|c|c|c|}
\hline Index & FC & SP & TF & SWM & WS \\
\hline$C_{11}$ & 0.482 & 0.469 & 0.508 & 0.384 & 0.378 \\
\hline$C_{12}$ & 0.401 & 0.546 & 0.522 & 0.329 & 0.401 \\
\hline$C_{13}$ & 0.504 & 0.470 & 0.490 & 0.385 & 0.371 \\
\hline$C_{14}$ & 0.493 & 0.493 & 0.410 & 0.478 & 0.343 \\
\hline$C_{15}$ & 0.457 & 0.457 & 0.493 & 0.450 & 0.371 \\
\hline$C_{16}$ & 0.351 & 0.498 & 0.526 & 0.415 & 0.424 \\
\hline$C_{21}$ & 0.437 & 0.514 & 0.514 & 0.334 & 0.411 \\
\hline$C_{22}$ & 0.361 & 0.518 & 0.559 & 0.334 & 0.422 \\
\hline$C_{23}$ & 0.305 & 0.471 & 0.558 & 0.436 & 0.427 \\
\hline$C_{24}$ & 0.396 & 0.448 & 0.534 & 0.431 & 0.414 \\
\hline$C_{31}$ & 0.473 & 0.553 & 0.437 & 0.374 & 0.374 \\
\hline$C_{32}$ & 0.462 & 0.560 & 0.470 & 0.316 & 0.389 \\
\hline$C_{33}$ & 0.463 & 0.454 & 0.488 & 0.438 & 0.387 \\
\hline$C_{34}$ & 0.297 & 0.567 & 0.483 & 0.427 & 0.418 \\
\hline$C_{41}$ & 0.345 & 0.525 & 0.525 & 0.410 & 0.402 \\
\hline$C_{42}$ & 0.453 & 0.428 & 0.577 & 0.297 & 0.437 \\
\hline$C_{43}$ & 0.406 & 0.507 & 0.498 & 0.406 & 0.406 \\
\hline$C_{44}$ & 0.362 & 0.320 & 0.543 & 0.510 & 0.469 \\
\hline$C_{51}$ & 0.310 & 0.465 & 0.501 & 0.510 & 0.419 \\
\hline$C_{52}$ & 0.226 & 0.586 & 0.544 & 0.368 & 0.418 \\
\hline$C_{61}$ & 0.350 & 0.613 & 0.525 & 0.337 & 0.337 \\
\hline$C_{62}$ & 0.392 & 0.430 & 0.569 & 0.407 & 0.415 \\
\hline$C_{63}$ & 0.358 & 0.603 & 0.435 & 0.442 & 0.351 \\
\hline & & & & & \\
\hline
\end{tabular}

Step 2: From the weights (Table 7) and the normalized evaluation matrix, the weighted performance data were calculated.

Step 3: According to Eq. (7), the positive ideal solution (PIS) and the negative ideal solution (NIS) were defined. Then, this study calculated the distances of each project to the PIS and the NIS according to Eq. (8). The results are shown in Table 9, which shows that smart pension (SP) had the shortest distance from the PIS and longest from the NIS. This result indicates that SP is the best of the five projects. On the contrary, the smart washing machine (SWM) was inferior to the other four projects because it was farthest from the PIS and closest to the NIS.

Step 4: Finally, this paper calculated the relative closeness of each project according to Eq. (9) and their ranking (Table 10). The higher the relative closeness of the project, the better of the performance of the project. The results show that SP, TF and FC were the top three best performing projects and SW and SWM were relatively weak. 
Table 9. The distance of five projects to PIS and NIS

\begin{tabular}{|c|c|c|}
\hline Project & Distance to PIS & Distance to NIS \\
\hline FC & 0.0345 & 0.0234 \\
\hline SP & 0.0123 & 0.0422 \\
\hline TF & 0.0133 & 0.0414 \\
\hline SWM & 0.0420 & 0.0165 \\
\hline SW & 0.0346 & 0.0179 \\
\hline
\end{tabular}

Table 10. Project relative closeness ranking table

\begin{tabular}{|c|c|c|}
\hline Project & Relative Closeness & Ranking \\
\hline FC & 0.404 & 3 \\
\hline SP & 0.774 & 1 \\
\hline TF & 0.757 & 5 \\
\hline SWM & 0.283 & 4 \\
\hline SW & 0.340 & \\
\hline
\end{tabular}

\section{Discussion}

As seen in Table 7 , team quality $\left(D_{1}, 30.8 \%\right)$, the business model $\left(D_{3}, 21.2 \%\right)$ and entrepreneurship ability $\left(D_{2}, 20 \%\right)$ are the three most important dimensions for measuring the quality of the entrepreneurial projects. Entrepreneurial team is a collective formed for entrepreneurship. It makes the members unite to form the interaction of mutual influence. Psychologically aware of the existence of other members and the feeling and working spirit of mutual belonging. This kind of collective is different from the social group in the general sense. It exists in the enterprise, but it is beyond the individual, leader and organization because of the entrepreneurial relationship. Business model innovation is an essential indicator for evaluating any new venture. Many projects fail because they directly replicate the business model of other projects. A sustainable and innovative business model will enable entrepreneurial projects to have continuous vitality (Geissdoerfer et al., 2018; Bouwman et al., 2019). Innovation is the foundation for the successful operation of entrepreneurial projects and the most intuitive embodiment of entrepreneurial capabilities (Fernhaber \& Stark, 2019). Our results are confirmed by the relevant literature. Team quality, the business model and entrepreneurial ability are the three most important dimensions for evaluating entrepreneurial projects.

Innovative ability $\left(C_{22}\right)$ accounts for $9.5 \%$ of the evaluation system's weight and has the highest weight among all 23 criteria (Table 7). Innovation is the soul of any enterprise's development. World-class companies such as Alibaba, Amazon, and Google have been committed to continuous innovation. Therefore, when evaluating an entrepreneurial project, judges pay great attention to the innovation ability of the project. As is shown in Table 8, it is clear that SP and TF scored higher on innovation ability than the other three projects when the experts evaluated the five projects. 
Team leader ability $\left(C_{11}\right)$ and value proposition $\left(C_{32}\right)$ ranked second and third with weights of $9.3 \%$ and $8.8 \%$, respectively. As the founder of the project, the team leader's leadership ability and style have important impacts on the successful incubation and development of the project. The style of the leader directly determines the values of the team and the culture of the company (Rego et al., 2017). The project is accepted by the market mainly based on whether its products can meet customers' needs. Therefore, the value proposition is also an important indicator for the expert to assess whether the project is mature. For these reasons, FC, SP and TF scored higher on these two criteria than the other two projects.

Although FC had a high score in regard to team leader competence, it ranks third because of its poor performance in value sharing $\left(C_{34}\right)$, initial funds $\left(C_{51}\right)$ and future entrepreneurial financing $\left(C_{52}\right)$. The members of the SWM team and the SW team are full of entrepreneurial enthusiasm for their projects, and the team spirits are high, but the projects' degree of innovation, business models, market environments and financial indicators are less than those of the other three projects.

Gupta and Barua (2017) suggests a sensitivity analysis method for investigating the effect of criterion weights. To explore the influence of the weights, innovative ability $\left(C_{22}\right)$ were selected as an independent variable, and set it from 0.1 to 0.9 (Table 11). The weights of the other 22 criteria are proportionally changed according to its weight changes. The evaluation performances of these five projects were then ranked using the TOPSIS method over 9 different runs. By comparing the ranking changes, it can be seen that after the third round, FC changed in rank from third to fourth, SP changed in rank from first to second, TF changed in rank from second to first, and WS changed in rank from fourth to fifth. There was no change in the ranking of SWM. This change means that innovative ability $\left(C_{22}\right)$ is the most important criterion, but when its weight value exceeds 0.2 , the weight of the other important criteria such as the team leader ability $\left(C_{11}\right)$ and value proposition $\left(C_{32}\right)$, will decrease. Eventually, the performance ranking of the projects will be changed. Therefore, the weights of the criteria will significantly affect the final ranking, and the applying the BWM method to assess the criterion weights is necessary.

Table 11. Analysis of the Sensitivity of Projects under various criteria

\begin{tabular}{|c|c|c|c|c|c|c|}
\hline Runs & Weight & FC & SP & TF & SWM & WS \\
\hline 1 & 0.095 & 3 & 1 & 2 & 5 & 4 \\
\hline 2 & 0.1 & 3 & 1 & 2 & 5 & 4 \\
\hline 3 & 0.2 & 4 & 2 & 1 & 5 & 3 \\
\hline 4 & 0.3 & 4 & 2 & 1 & 5 & 3 \\
\hline 5 & 0.4 & 4 & 2 & 1 & 5 & 3 \\
\hline 6 & 0.5 & 4 & 2 & 1 & 5 & 3 \\
\hline 7 & 0.6 & 4 & 2 & 1 & 5 & 3 \\
\hline 8 & 0.7 & 4 & 2 & 1 & 5 & 3 \\
\hline 9 & 0.8 & 4 & 2 & 1 & 5 & 3 \\
\hline 10 & 0.9 & 4 & 2 & 1 & 5 & 3 \\
\hline
\end{tabular}




\section{Conclusions}

The growth rate of Chinese entrepreneurship projects is increasing under the encouragement and stimulation of the governments, schools and markets. Therefore, it is necessary and timely to evaluate the performance of entrepreneurial projects. This paper proposes a MCDM model for evaluating entrepreneurial projects. Among the six dimensions and 23 criteria studied in this paper, the most important dimensions affect entrepreneurship project evaluation are team quality, the business model and entrepreneurship ability. The dimensions of the market environment, financial indicators and entrepreneurial environment are not considered because most of the projects are still at the creative stage.

In summary, the primary goal of entrepreneurship is to maintain high team quality, continuously improve the team entrepreneurial ability, and adhere to the correct business model to improve the conversion rate of entrepreneurial projects. Secondly, due to the weak anti-risk ability of an entrepreneurial team in the face of competition in a cruel market, the control and prevention of risks in unknown markets should be strengthened, including the overall estimation and management of competitors and financial funds. Finally, although the entrepreneurial environment is a relatively unimportant dimension, projects can still pay more attention to government policy support and social sustainable development.

The findings are related to stakeholders in entrepreneurial project evaluations and the project finance industry, which include startup incubators, entrepreneurial competitions, venture capital firms, entrepreneurship education management, etc. The results can be used to assist the entrepreneurial project evaluation system to improve the fairness and systemicity of entrepreneurial project evaluations.

Although the applicability and stability of the proposed model are confirmed, some limitations still need to be resolved. It seems that the sample size of this paper is rather small, and this study hopes that future studies will collect more cases from target countries to make the conclusions more generalizable. Moreover, interviewing more experts in the BWM context is another future research topic.

\section{Acknowledgements}

The authors are extremely grateful to the editorial team's valuable comments on improving the quality of this article.

\section{Funding}

This research received no external funding.

\section{Author contributions}

Qigan Shao analyzed the data, reviewed the literature, and wrote the paper. Sung-Shun Weng and James J. H. Liou designed the research and co-wrote and revised the paper. Peiyao Su completed the article writing and formatting. James J. H. Liou formatted the article as well. 


\section{Disclosure statement}

The authors declare no conflict of interest.

\section{References}

Allam, Z., \& Dhunny, Z. A. (2019). On big data, artificial intelligence and smart cities. Cities, 89, 80-91. https://doi.org/10.1016/j.cities.2019.01.032

Alvarez, S. A., \& Busenitz, L. W. (2001). The entrepreneurship of resource-based theory. Journal of Management, 27(6), 755-775. https://doi.org/10.1177/014920630102700609

Aparicio, S., Urbano, D., \& Gómez, D. (2016). The role of innovative entrepreneurship within Colombian business cycle scenarios: A system dynamics approach. Futures, 81, 130-147. https://doi.org/10.1016/j.futures.2016.02.004

Åstebro, T., Bazzazian, N., \& Braguinsky, S. (2012). Startups by recent university graduates and their faculty: implications for university entrepreneurship policy. Research Policy, 41(4), 663-677. https://doi.org/10.1016/j.respol.2012.01.004

Avlonitis, G. J., \& Salavou, H. E. (2007). Entrepreneurial orientation of SMEs, product innovativeness, and performance. Journal of Business Research, 60(5), 566-575. https://doi.org/10.1016/j.jbusres.2007.01.001

Beltramello, A., Haie-Fayle, L., \& Pilat, D. (2013). Why new business models matter for green growth. OECD Green Growth, 12, 1-108. https://doi.org/10.1787/22260935

Bocken, N. M. P., Short, S. W., Rana, P., \& Evans, S. (2014). A literature and practice review to develop sustainable business model archetypes. Journal of Cleaner Production, 65(15), 42-56. https://doi.org/10.1016/j.jclepro.2013.11.039

Bouwman, H., Nikou, S., \& Reuve, M. D. (2019). Digitalization, business models, and SMEs: How do business model innovation practices improve performance of digitalizing SMEs? Telecommunications Policy, 43(9), 101828. https://doi.org/10.1016/j.telpol.2019.101828

Chen, J., Chen, L., Chen, J. Y., \& Xie, K. F. (2018). Mechanism and policy combination of technical sustainable entrepreneurship crowdfunding in China: A system dynamics analysis. Journal of Cleaner Production, 177(10), 610-620. https://doi.org/10.1016/j.jclepro.2017.12.217

Chesbrough, H., \& Rosenbloom, R. S. (2002). The role of the business model in capturing value from innovation: evidence from Xerox Corporation's technology spinoff companies. Industrial and Corporate Change, 11(3), 529-555. https://doi.org/10.1093/icc/11.3.529

Colombo, M. G., D’Adda, D., \& Quas, A. (2019). The geography of venture capital and entrepreneurial ventures' demand for external equity. Research Policy, 48(5), 1150-1170. https://doi.org/10.1016/j.respol.2018.12.004

Cooke-Davis, T. (2002). The real success factors on projects. International Journal of Project Management, 20(3), 185-190. https://doi.org/10.1016/S0263-7863(01)00067-9

Cui, J., Sun, J. H., \& Bell, R. (2019). The impact of entrepreneurship education on the entrepreneurial mindset of college students in China: The mediating role of inspiration and the role of educational attributes. The International Journal of Management Education (in press). https://doi.org/10.1016/j.ijme.2019.04.001

Dahaj, A. S., \& Cozzarin, B. P. (2019). Government venture capital and cross-border investment. Global Finance Journal, 41, 113-127. https://doi.org/10.1016/j.gf.2019.03.001

David, H. H., Edward, B. R., \& Charles, E. E. (2007). Entrepreneurs from technology-based universities: evidence from MIT. Research Policy, 36(5), 768-788. https://doi.org/10.1016/j.respol.2007.03.001 
Duan, Y. Q., Edwards, J. S., \& Dwivedi, Y. K. (2019). Artificial intelligence for decision making in the era of Big Data evolution. Challenges and Research Agenda. International Journal of Information Management, 48, 63-71. https://doi.org/10.1016/j.ijinfomgt.2019.01.021

Durmuşoğlu, Z. D. U. (2018). Assessment of techno-entrepreneurship projects by using Analytics Hierarchy Process (AHP). Technology in Society, 54, 41-46. https://doi.org/10.1016/j.techsoc.2018.02.001

Fernhaber, S. A., \& Stark, A. Y. (2019). Biomimicry: New insights for entrepreneurship scholarship. Journal of Business Venturing Insights, 12, e00137. https://doi.org/10.1016/j.jbvi.2019.e00137

Finkle, T. A., \& Deeds, D. (2001). Trends in the market for entrepreneurship faculty, 1989-1998. Journal of Business Venturing, 16(6), 613-630. https://doi.org/10.1016/S0883-9026(99)00051-8

Fjeldstad, Ø. D., \& Snow, C. C. (2018). Business models and organization design. Long Range Planning, 51(1), 32-39. https://doi.org/10.1016/j.lrp.2017.07.008

Frid, C. J., Wyman, D. M., \& Gartner, W. B. (2016). Low-wealth entrepreneurs and access to external financing. International Journal of Entrepreneurial Behavior \& Research, 22(4), 1-25. https://doi.org/10.1108/IJEBR-08-2015-0173

Fuentelsaz, L., González, C., \& Maicas, J. P. (2019). Formal institutions and opportunity entrepreneurship. The contingent role of informal institutions. Business Research Quarterly, 22(1), 5-24. https://doi.org/10.1016/j.brq.2018.06.002

Gartner, W. B. (1990). What are we talking about when we talk about entrepreneurship? Journal of Business Venturing, 5(1), 15-28. https://doi.org/10.1016/0883-9026(90)90023-M

Geissdoerfer, M., Vladimirova, D., \& Evans, S. (2018). Sustainable business model innovation: A review. Journal of Cleaner Production, 198(10), 401-416. https://doi.org/10.1016/j.jclepro.2018.06.240

Guo, S., \& Zhao, H. (2017). Fuzzy best-worst multi-criteria decision-making method and its applications. Knowledge-Based Systems, 121(1), 23-31. https://doi.org/10.1016/j.knosys.2017.01.010

Gupta, H. (2018). Assessing organizations performance on the basis of GHRM practices using BWM and Fuzzy TOPSIS. Journal of Environment Management, 226, 201-216. https://doi.org/10.1016/j.jenvman.2018.08.005

Gupta, H., \& Barua, M. K. (2017). Supplier selection among SMEs on the basis of their green innovation ability using BWM and fuzzy TOPSIS. Journal of Cleaner Production, 152(20), 242-258. https://doi.org/10.1016/j.jclepro.2017.03.125

Gupta, H., \& Barua, M. K. (2018). A framework to overcome barriers to green innovation in SMEs using BWM and Fuzzy TOPSIS. Science of the Total Environment, 633, 122-139. https://doi.org/10.1016/j.scitotenv.2018.03.173

Hienerth, C., Keinz, P., \& Lettl, C. (2011). Exploring the nature and implementation process of user-centric business models. Long Range Planning, 44(5), 344-374. https://doi.org/10.1016/j.lrp.2011.09.009

Hwang, C. L., \& Yoon, K. (1981). Multiple attributes decision making methods and applications. Springer. https://doi.org/10.1007/978-3-642-48318-9_3

Ika, L. A. (2009). Project success as a topic in project management journals. Project Management Journal, 40(4), 6-19. https://doi.org/10.1002/pmj.20137

İrengün, O., \& Arıkboğa, Ş. (2015). The effect of personality traits on social entrepreneurship intentions: A field research. Procedia - Social and Behavioral Sciences, 195(3), 1186-1195. https://doi.org/10.1016/j.sbspro.2015.06.172

Jensen, T. L. (2014). A holistic person perspective in measuring entrepreneurship education impact Social entrepreneurship education at the Humanities. International Journal of Management Education, 12(3), 349-364. https://doi.org/10.1016/j.ijme.2014.07.002

Kalbar, P. P., Karmakar, S., \& Asolekar, S. R. (2012). Technology assessment for wastewater treatment using multiple-attribute decision-making. Technology in Society, 34(4), 295-302.

https://doi.org/10.1016/j.techsoc.2012.10.001 
Khalili-Damghani, K., \& Sadi-Nezhad, S. (2013). A hybrid fuzzy multiple criteria group decision making approach for sustainable project selection. Applied Soft Computing, 13(1), 339-352. https://doi.org/10.1016/j.asoc.2012.07.030

Kim, W., \& Kim, M. (2015). Reference quality-based competitive market structure for innovation driven markets. International Journal of Research in Marketing, 32(3), 284-296. https://doi.org/10.1016/j.ijresmar.2014.10.003

Kirkwood, J., Dwyer, K., \& Gray, B. (2014). Students' reflections on the value of an entrepreneurship education. The International Journal of Management Education, 12(3), 307-316. https://doi.org/10.1016/j.ijme.2014.07.005

Kumar, A., A, A., \& Gupta, H. (2020). Evaluating green performance of the airports using hybrid BWM and VIKOR methodology. Tourism Management, 76, 103941. https://doi.org/10.1016/j.tourman.2019.06.016

Lee, Y. S., \& Eesley, C. (2018). The persistence of entrepreneurship and innovative immigrants. Research Policy, 47(6), 1032-1044. https://doi.org/10.1016/j.respol.2018.03.007

Liang, F. Q., Brunelli, M., \& Rezaei, J. (2020). Consistency issues in the best worst method: Measure and thresholds. Omega, 96, 102175. https://doi.org/10.1016/j.omega.2019.102175

Lucia, C., De, Balena, P., \& Melone, M. R. S. (2016). Policy, entrepreneurship, creativity and sustainability: The case of 'Principi Attivi' ('Active Ingredients') in Apulia Region (southern Italy). Journal of Cleaner Production, 135, 1461-1473. https://doi.org/10.1016/j.jclepro.2016.06.068

Mandel, R., \& Noyes, E. (2016). Survey of experiential entrepreneurship education offerings among top undergraduate entrepreneurship programs. Education + Training, 58(2), 164-178. https://doi.org/10.1108/ET-06-2014-0067

Mou, Q., Xu, Z. S., \& Liao, H. C. (2016). An intuitionistic fuzzy multiplicative best-worst method for multi-criteria group decision making. Information Sciences, 374, 224-239. https://doi.org/10.1016/j.ins.2016.08.074

Neumeyer, X., \& Santos, S. C. (2018). Sustainable business models, venture typologies, and entrepreneurial ecosystems: A social network perspective. Journal of Cleaner Production, 172, 4565-4579. https://doi.org/10.1016/j.jclepro.2017.08.216

Patzelt, H., Behrens, J., Wolfe, M. T., \& Shepherd, D. A. (2020). Perceived project transition support and employees' assessments of entrepreneurial project performance. Journal of Business Venturing, 35, 105887. https://doi.org/10.1016/j.jbusvent.2018.06.005

Paul, J., \& Shrivatava, A. (2016). Do young managers in a developing country have stronger entrepreneurial intentions? Theory and debate. International Business Review, 25(6), 1197-1210. https://doi.org/10.1016/j.ibusrev.2016.03.003

Pickernell, D., Packham, G., Jones, P., Miller, C., \& Thomas, B. (2011). Graduate entrepreneurs are different: they access more resources? International Journal of Entrepreneurial Behavior \& Research, 17(2), 183-202. https://doi.org/10.1108/13552551111114932

Pirzada, K., Wickramasinghe, D., \& Moens, G. A. (2015). The role of entrepreneur in residence towards the students'entrepreneurial performance: A study of entrepreneurship learning process at Ciputra University, Indonesia. Procedia - Social and Behavioral Sciences, 211, 972-976. https://doi.org/10.1016/j.sbspro.2015.11.129

Razeghian, M., \& Weber, T. A. (2019). Strategic durability with sharing markets. Sustainable Production and Consumption, 19, 79-96. https://doi.org/10.1016/j.spc.2019.02.007

Rahimi, S., Hafezalkotob, A., Monavari, S. M. Hafezalkotob, A., \& Rahimi, R. (2020). Sustainable landfill site selection for municipal solid waste based on a hybrid decision-making approach: Fuzzy group BWM-MULTIMOORA-GIS. Journal of Cleaner Production, 248, 11986.

https://doi.org/10.1016/j.jclepro.2019.119186 
Rego, A., Owens, B., Leal, S., Melo, A., Cunha, M. P., Goncalves, L., \& Ribeiro, P. (2017). How leader humility helps teams to be humbler, psychologically stronger, and more effective: A moderated mediation model. The Leadership Quarterly, 28(5), 649-658. https://doi.org/10.1016/j.leaqua.2017.02.002

Rezaei, J. (2015). Best-worst multi-criteria decision-making method. Omega, 53, 49-57. https://doi.org/10.1016/j.omega.2014.11.009

Rezaei, J., Hemmes, A., \& Tavasszy, L. (2017). Multi-criteria decision-making for complex bundling configurations in surface transportation of air freight. Journal of Air Transport Management, 61, 95-105. https://doi.org/10.1016/j.jairtraman.2016.02.006

Salimi, N., \& Rezaei, J. (2016). Measuring efficiency of university industry Ph.D. projects using best worst method. Scientometrics, 109, 1911-1938. https://doi.org/10.1007/s11192-016-2121-0

Salunke, S., Weerawardena, J., \& McColl-Kennedy, J. R. (2013). Competing through service innovation: The role of bricolage and entrepreneurship in project-oriented firms. Journal of Business Research, 66(8), 1085-1097. https://doi.org/10.1016/j.jbusres.2012.03.005

Soares, F. O., Sepúlveda, M. J., Monteiro, S., Lima, R. M., \& Dinis-Carvalho, J. (2013). An integrated project of entrepreneurship and innovation in engineering education. Mechatronics, 23(8), 987-996. https://doi.org/10.1016/j.mechatronics.2012.08.005

Tsai, W. H., \& Kuo, H. C. (2011). Entrepreneurship policy evaluation and decision analysis for SMEs. Expert Systems with Applications, 38(7), 8343-8351. https://doi.org/10.1016/j.eswa.2011.01.022

Wen, J. W., Yang, D., Feng, G. F., Dong, M. Y., \& Chang, C. P. (2018). Venture capital and innovation in China: The non-linear evidence. Structural Change and Economic Dynamics, 46, 148-162. https://doi.org/10.1016/j.strueco.2018.05.004

Yang, A., Li, Y. F., Liu, C. S., Li, J., Zhang, Y. Z., \& Wang, J. H. (2019). Research on logistics supply chain of iron and steel enterprises based on block chain technology. Future Generation Computer Systems, 101, 635-645. https://doi.org/10.1016/j.future.2019.07.008

Yang, M., \& Gabrielsson, P. (2017). Entrepreneurial marketing of international high-tech business-tobusiness new ventures: A decision-making process perspective. Industrial Marketing Management, 64, 147-160. https://doi.org/10.1016/j.indmarman.2017.01.007

Yoon, K. P., \& Kim, W. K. (2017). The behavioral TOPSIS. Expert Systems with Applications, 89, 266272. https://doi.org/10.1016/j.eswa.2017.07.045

You, X. S., Chen, T., \& Yang, Q. (2016). Approach to multi-criteria group decision-making problems based on the best-worst-method and ELECTRE method. Symmetry, 8(9), 95. https://doi.org/10.3390/sym8090095

Zhang, Z. L. (2018). Independent innovation promotes the continuous development of Chinese patents. National Bureau of Statistics. http://www.stats.gov.cn/tjsj/sjjd/201804/t20180416_1593979.html

Zhu, H. B., Zhang, K., \& Ogbodo, U. S. (2017). Review on innovation and entrepreneurship education in Chinese universities during 2010-2015. Journal of Mathematics Science and Technology Education, 13(8), 5939-5948. https://doi.org/10.12973/eurasia.2017.01042a 